\title{
The Dialectic of Reciprocal Impact between Arabic and English: Egyptian Colloquial Arabic as a Model
}

\author{
Amany Hamed Mohamed \\ Lecturer in Linguistics, English Department \\ Faculty of Arts, New Valley University \\ hamed.amany@ymail.com \\ amany.hussien@artnv.au.edu.eg
}

\begin{abstract}
The study investigates the issue of the reciprocal impact between Arabic and English. It demonstrates the reasons that make English stop being inspired by Arabic. It also sheds light on the effect of Englishization on culture-specific words in the Egyptian society. The study illustrates the effect of westernization and globalization on the Arabic language. It raises some questions: Will the continuous injection of English words into the Egyptian spoken language affect the Arabic language and people's cultural identity? There is another question which is if English dominates the Arabic language in its homeland, will it be spoken by the west that cherishes its language? The study sample consists of 15 recorded hours of various talk shows that discuss different topics like fashion, health, beauty, cooking, medicine, economics, business, horoscope...etc. Analysis of the data is based on Carol Myers-Scotton theories: Markedness Model and Matrix Language Frame Model (1993a, 1993b). It has been noticed that English is commonly used because it is stylish and trendy. It has been suggested that there is a relationship between the topic being discussed and the frequency of English being used.
\end{abstract}

Key words: reciprocal impact, Egyptian colloquial Arabic, Markedness theory, cultural identity

\section{Introduction}

Language is an organism that grows, develops, spreads out and fades away, and there is no doubt that language is influenced by the nation's civilization, culture, traditions, attitudes and everything related to it. Therefore, languages are the truest record of the history and civilization of nations. With the expansion of these civilizations, the language of communication rises, and 
evolves to become solid and well established in the face of language conflicts. A look at the Arabic language confirms that it is the truest example, so shortly after the descent of the Holy Quran, it became the language of both mental and religious sciences in the middle ages, it also left traces that witness the genius of our Arab Muslim scholars throughout the ages. It was not limited to the Arabs, but the Arabic language spread and went beyond the borders of the Arabian Peninsula till it was mastered and learned by non-Arabs - like Ebn Gene and Sibawayh. Arabic was the language of the civilized world for several centuries which was the period of flourishing of the Arab Islamic civilization. At this time, many languages were influenced by Arabic until Arabic began to be affected by other languages as a result of cultural communication with each other. English is one of the most important languages which had a reciprocal effect on Arabic noticeably in the recent years; therefore, this study attempts to present the issue of the reciprocal influence between Arabic and English.

\section{Literature Review}

Previous studies are divided into three parts: studies which focus on the effect of the second language (English) on the mother tongue (Arabic), studies which focus on the effect of globalization on Arabic, and studies that investigate the effect of English dominance on cultural identity. Among the studies concentrating on the effect of second language is Hanani (2009). He conducted a study to determine the impact of the second language (English) proficiency on the use of Arabic language by the Arab youth, which might cause the loss of Arabic. The study sample consisted of a group of students aged between 14-16 years of different nationalities from five international schools in Dubai and Sharjah. The results revealed that both students and parents were unaware of the consequences of the excessive usage of English.

With regard to studies concentrating on the status of the Arabic language in the Arabic-speaking world, Hassan (2012) described the relationship between language and national identity. He investigated the problems that face the Arabic language in the age of globalization such as hybridization and using English instead of Arabic as a medium of instruction. He also suggested language planning activities for protecting the Arabic language. The study was mainly concerned with the modern standard Arabic; the language of writing and formal expressions.

The situation of classical Arabic in the Arab world was also examined by Benkharafa (2013). He saw that Arabization is an urgent necessity that could revitalize the Arabic language and help the Arab nation regain its linguistic 
independence. It focused on the challenges that face Arabic and Arabization in the present century and the problems that affected the power of the classical Arabic refuting the misconceptions associated with Arabization.

The phenomenon of switching from Arabic to English in informal context was examined by Ben Nafa (2013) by recording six- hour informal conversations. It was observed that the use of English words is subject to the Arabic grammar. The study showed that linguistic proficiency and age were among the factors that affected switching from Arabic to English. Asimilar study is of Akeel (2016) who examined code switching in Arabic/English interview between two Arabic women in the context of hair and skin care in Dubai. The results showed that switching from Arabic to English was extremely used in the interview. He argued that code switching was mostly used for grabbing the audience attention, emphasizing points, and showing knowledge of topic-related terms.

Hamouda (2015) who examined the reasons for switching from Arabic to English in the Egyptian program "shabab beek". The data consisted of four hours and forty-five minutes of the talk show episodes. The study revealed that the percentage of the switched words used by program hosts and guests was more than the percentage of the switched words used callers, and this might be due to the limited number of calls the program received. It was noted that the speakers used names followed by adjectives and noun phrases. The analysis of the sample showed eight functions for switching from Arabic to English, including retrieving an Arabic expression, quotation, reiteration, academic or technical terms, euphemism, association with certain domains, and objectivization. Another study conducted to examine the foreign influence on Arabic in Egypt was Aziz's study (1967). He was concerned with the influence of English grammar, syntax, idiom and style upon contemporary literary Arabic works: books and press. A questionnaire was answered by three of the authors whose works were treated in the study: Naguib Mahfouz, Ahmed Zaki and Jabra Ibrahim Jabra. The study examined the western cultural influence on the creation of the modern pattern of literary Arabic in Egypt.

For studies that tackled the effect of English on cultural identity, Al Allaq (2014) examined the influence of globalization on the Arabic language. He investigated the importance of language in sustaining people's cultural identity. He also examined the impact of globalization on languages in general and on the 
language of the United Arab Emirates in particular. Dahan (2015) conducted a study on how Arab students perceived their Arab identity in an English medium university in the United Arab Emirates. The findings of the study revealed that Arab youth had complex identity. They saw English as a global language for communication. They also saw that there was no strict bond between Arabic and Arabic identity. Code switching was not an identity marker. A similar study was conducted by Belhiah \& Al-hussien (2016) who examined the impact of English medium instruction on students' Arab identity and mastery of Arabic. The study was undertaken at two high schools in UAE. Results suggested that students became gradually more competent in English at the expense of Arabic even though the students were aware that Arabic is part and parcel of the Arabic identity.

Alfarhan (2016) discussed the globalization of English and its influence on cultural identity. The study investigated the effect of the second language acquisition on cultural identity. Knowing English helps individuals get a good job. A similar study was of Hopkyns (2017) who discussed the rapid spread of English both in education and everyday communications. The study investigated the effect of global English on cultural identity in the United Arab Emirates through the perspective of three groups studying at the university. The finding of the study showed that most of the participants had positive view towards English as it is connected with wider world, education, future careers and global communication. Arabic is associated to religion, daily home life and tradition.

It could be noticed that very few studies have discussed the dialectic of the reciprocal impact between Arabic and English and the effect of westernization and globalization on both the spoken colloquial Arabic and the cultural identity in Egypt.

\section{Impact of Arabic on English}

Arabic is considered the first language of the Islamic world, and it is the language of the Holy Quran. Arabic has served as the main vehicle of Islamic culture (Benkharafa, 2013, 202). It is the most spoken language among the Semitic language group, and it is one of the most widely spoken languages in the world. The Islamic religion directly influenced its spread across the borders of the Arabian Peninsula.

The Arabic language is divided into two parts: Southern Arabic and Northern Arabic. Southern Arabic: known to Arabic linguists as 
Himyaritic language, its home is Yemen and Southern Arabia, and it is divided into two parts: the Sabean and the Ma'eenyia, and many of its inscriptions have reached us between the twelfth century $\mathrm{BC}$ and the sixth century AD.

The Arabic language that we mean in this study is Northern Arabic; which is the language of the central and northern Arabia, and it is called in our custom (Classical Arabic), and being the language of the Holy Quran, this language is immortal, so it has spread widely more than any other language in the world, and for all Muslims, it is the only permissible language of worship; as a result Northern Arabic outperformed many of the languages spoken by Muslims. In addition to Classical Arabic there were different Arabic dialects in the Arabian Peninsula.

When language contacts, linguistic items are transferred from one language to another as a result of borrowing words. From the 8th to 12th centuries, Arabic was the language of science. It was the language of ArabIslamic civilization. Many Arabic works have been translated in the fields of medicine, chemistry, philosophy and mathematics. At this time, Europe was in the Dark Ages and the Islamic empire grew in the Mediterranean. As a result, Arabic became an influential language among other cultures. English is one of the languages which was greatly inspired by Arabic by borrowing words directly from Arabic or through other languages that were influenced by Arabic. The situation has changed today. English is the language that is mostly used around the world due to advanced technology, Hollywood movies and pop cultures.

There are other examples that confirm the Arabic language's influence on English. Al-Khawarizmi introduced countless words in Latin and English, such as: Algebra which is taken from الجبر äljabr, which means 'reconnecting the broken parts', and الجبر aljabr which means 'to make the poor man rich', or 'splint a broken bone'. In chemistry there are many words, such as: Elixir الإكسير al'ksir, Talismang الطلسم. altalsm in the Arabic dictionaries is 'a composite material that is dumped on the simple metal and turns it into gold according to the beliefs of the ancient people'. And it was said that it is an imaginary drink that prolongs life.

Other words were transferred to English as a result of the cultural influence. There were more than a thousand Arabic words that entered the English language in many scientific fields; such as medicine, astronomy, chemistry, surgery, biology. It is worth mentioning here the role of Ibn alHaytham, the pioneer of optics who made great contributions in manufacturing 
the camera, which was called at that time "قمرة" qamara which means in Arabic 'the dark room', and the English term "camera" was derived from it.

A lot of words in English are from an Arabic origin like 'Admiral' أمير

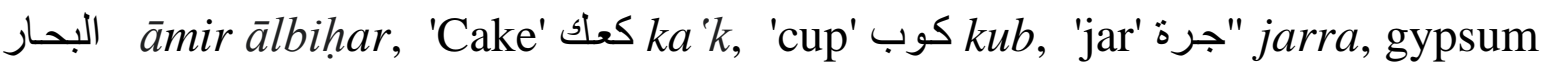

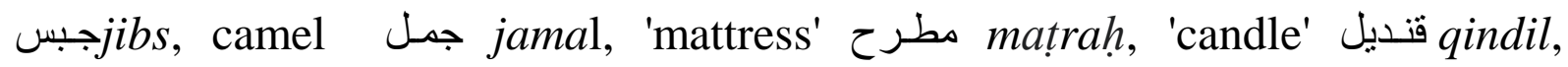

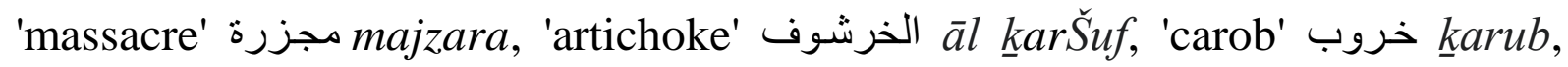

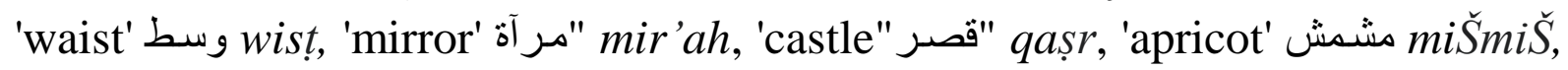

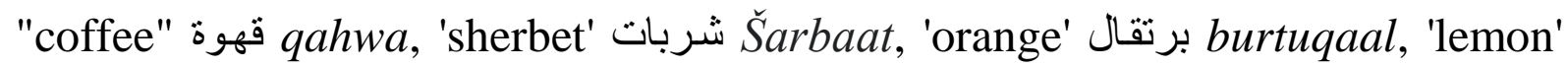

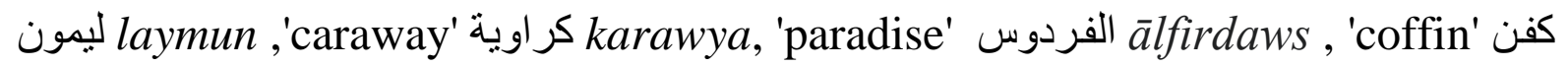

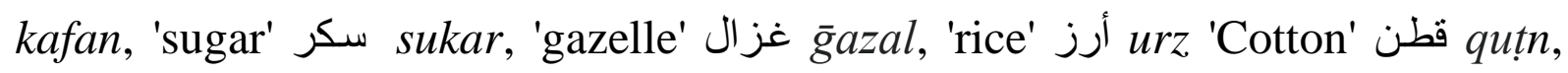

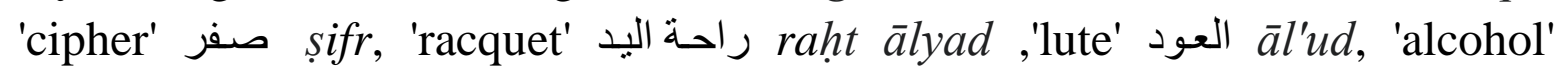

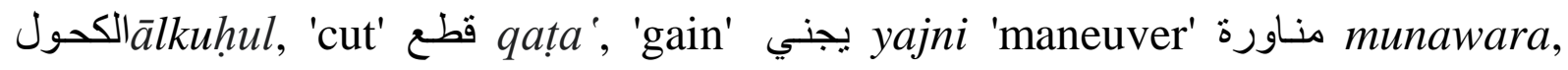

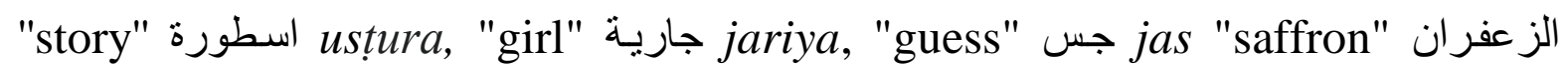

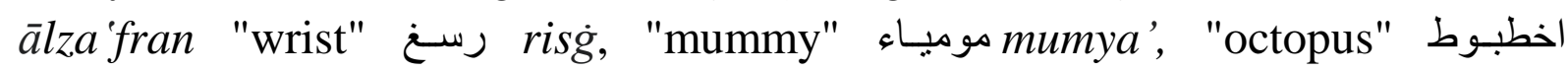
.uktubut. etc. In colloquial Arabic we can find words like "اليطاء" âlit from the English word "elite", "ورشة" wař̌ah from "workshop", "دون" dun from "down" ,

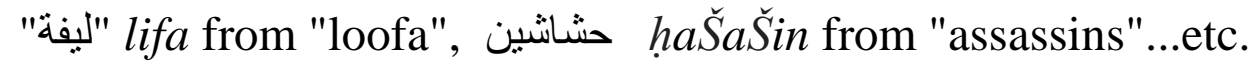

The English language contains more than 10,000 words of Arabic origin but this was between the eighth and twelfth century, due to the flourishing of Islamic civilization. What about scientific research? Everything is in English, books, scientific journals and others. Unfortunately nowadays the Arabic language cannot keep up with the boom of scientific and technological terms.

\section{Impact of English on Arabic}

Recently, we notice the rapid spread of the English language to become the most widely used in different societies, countries and political forums at the international level. This is due to several reasons, the most important is the increasing influence of the western culture. In addition, English is considered one of the most important aspects of modernity and urbanization. Because of the dominance of the English language, some of its terms, vocabulary and even expressions began to leak to Arabic language, and replaced it in many fields such as technology, media, politics, daily transactions, clothing, food and beverage names.

One of the most important factors that has helped a lot of English vocabulary to affect the Arab culture is the western contact, which has resulted in many changes, the most important of which is borrowing. The superiority of 
western civilizations over their Arabic counterparts has led to the dominance of the language of the advanced civilizations; this is because more advanced civilizations affect the people's taste and behavior in the less civilized countries, which leads to the spread of vocabulary produced by those civilizations.

\subsection{Englishization and culture-specific words in Egypt}

Englishization is the process of becoming English and has its impact on the local culture (Kachru, 1994). In Egypt, English spreads over the tongues of some strata of society - particularly the high class in the social ladder. Young people tend to use English in their daily life as a kind of urbanization and modernity. Another reason is the youth's fascination of the west films and electronic games, so we find phrases like: 'Take care', 'Never mind', 'I cannot do it', 'No problem', 'It is easy', ' It is ok', 'I miss you', 'See you', ...etc.

The issue of 'alienation' from the Arabic language has leaked clearly into the Egyptian society and affect the new generations. They are ready to imitate the west thinking that they are keeping up with civilization. This lies in their sense of inferiority. Their imitation of the west is a sort of compensation for this sense of inferiority, they feel psychological defeat against developed countries, the vanquished is often influenced by the winner.

Englishization has a sociocultural effect. It can be noticed in replacing Arabic words with other foreign ones imitating the west, which in turn leads to loss of identity, and the spread of 'cultural westernization' which means the blind tendency to imitate the west. Western character has affected the Egyptian culture and identity. This can be noticed in replacing Egyptian popular national food, which is part of the local culture, with English words. This phenomenon has crept to the Egyptian society among the high class people to enable them use the popular food names without being embarrassed, as these types of food are eaten by the lower classes. For examples they use the word 'Golden Berry' instead of حرنكش, 'Green Soup' instead of mulukiya ملوخية ' Egyptian Pasta' instead of الطعمية alta الكشرية 'alta 'miya 'Beans' instead of البليلة àlbililah, 'Mambo' instead of المبار àlmumbar, 'Golden Donuts' instead of الز الابيا alzalabya, 'Yucky fish' instead of الفيخ à lfisik 'Pop corn' instead

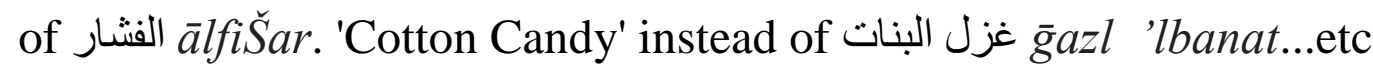

It is strange that, when foreigners visit Egypt, they use the Egyptian Arabic words of these national dishes because they are part of the national culture of the country. This is because a nation is "often associated with language as a marker of its identity which stamps the individual and the 
community with an imprint that is uniquely their own" (Suleiman, 2012, 425). When a society adopts another language and does not maintain its own, the level of competence and functional use of the mother tongue declines and deteriorates.

\section{Research questions}

The present study pursues the following research questions:

1- What are the reasons that make English stop being inspired by Arabic?

2. How does Englishization in the Egyptian society affect culture-specific words?

3- Does the continuous injection of English words into the Egyptian spoken language affect the Arabic language and people's cultural identity?

4. What types of code switching are employed by guests, presenters and callers and how frequently do they occur? Intersentential or intrasentential?

5. How Myers-Scotton's Markedness Model (1993a, 1993b) and Matrix Language Frame Model (2002) account for the data?

\section{Methodology}

\subsection{Data Collection}

The data collected of 15 recorded hours of various talk shows on T.V. and Youtube that discuss different topics like fashion, health, beauty, medicine, economics, business, horoscope...etc. Those programs have different welleducated guests (doctors, businessmen, parents, designers, chefs, sportsmen, actors).

\subsection{Data Analysis}

The data are analysed in line with Carol Myers-Scotton's models (1993a, 1993b, 2002). Carol Myers-Scotton is interested in code switching. She defines code switching as "the selection by bilinguals or multilinguals of forms from an embedded language (or languages) in utterances of a matrix language during the same conversation" (1993a: 4). Carol Myers-Scotton has devised a model to examine contact phenomena among a variety of languages since the 1990s. Her model consists of two aspects: structurally-based (the Matrix Language Frame [MLF]) and socially-based (the Markedness Theory) at both the interpersonal and community levels. The model aims to provide universal explanations for any instance of code switching in any language. Her model is chosen for analyzing data in this study because it is a multi-dimensional approach; sociopragmatic functions are integrated into structural explanation. 
According to Myers-Scotton, people in almost every community use at least two different speech styles. All linguistic varieties have social and psychological motivations when used in any speech community. Myers-Scotton (1993b) claims that there are socio-psychological motivations behind using code switching. Code choice always indexes a negotiation between the speaker and the addressee in any interaction. It helps bilinguals to express their shared identity and as well as a right and obligation balance (marked or unmarked code switching).

Myers-Scotton distinguishes between two types of code switching: 'marked' (conventional) and 'unmarked' (unexpected). Code switching is 'unmarked' if the linguistic choice is expected as a medium for an exchange. The unmarked choice is "only the choice which is most expected" (MyersScotton 1999: 1263). Frequency determines the unmarked choice. The unmarked choice is used more frequently in the corpus while the marked choice has limited frequency.

A 'Rights and Obligations' set is the theoretical construct of the Markedness theory and on which people base their expectations in any social interaction. RO sets are the established norms maintained in the community, Myers-Scotton claims, "RO sets are the elements ...that are directly derived from whatever societal factors are salient in the community and in the interaction type." (Myers-Scotton 2001: 9). Code choice reflects information about the identity and attitude of the speaker. Speakers are free to make such choices but they cannot expect how those choices will be interpreted by their interlocutors. Myers-Scotton (2001) sees that speakers have innate architecture that helps them to make a cost-benefit analysis of choices. The speaker connects between the situation and the RO sets and the linguistic choices that are marked or unmarked. With this respect to language choice, guests and presenters in this study use the unmarked code (Arabic) when they want to maintain their rights and obligations, whereas they use the marked code (English) when they want to make a change in these rights and obligation sets.

\subsubsection{Mixed Code in Talk Shows}

The media plays a serious role in attracting a large audience - especially among young people - to use English in their conversations and daily transactions; as media has linked English with urbanization and high culture. 
The media portrays the person who speaks English as a civilized intellectual who is familiar with multiculturalism, and at the same time, the classical Arabic speaker is depicted in traditional old costume that does not keep up with the present era, which reflects his intellectual backwardness.

The media has a great effect on cultural identity, so the mass media has begun to support English significantly. The cultural identity is the entity of any nation, if its entity was lost, its existence will be lost and its language will be weakened, so it has to be preserved.

The question here is if English dominates the Arabic language in its homeland, will it be spoken by the west that cherishes its language? Thus, if the Arabic language dies, the identity of the nation will die. Cultural identity means cultural uniqueness, and the word "culture" includes habits, behavior, values, language, traditions...etc. (Ibrahim, 2001).

It is the cultural identity that gives every society a special character, this special character stems from the legacies of the ancient Arab society. If language is the main mean of cultural and human communication, then the loss of language is a loss of culture and the loss of culture is a loss of identity. If the language is absent from the tongue, it will be absent from thought and conscience. When society adopts another language and does not preserve its own, then the level of proficiency and functional use of the mother tongue will decline and deteriorate (El- Khaldi, 2016).

One of the most important reasons that weakened the Arabic language is the cultural deterioration of civilization, and as Ibn Khaldun states that the loser is always fond of following the winner in his sigh, costume and all his conditions. The globalization of the media has produced the "Arab identity crisis" by alienating people from their old values and customs and converting to modern behaviors compatible with the age of globalization. This doesn't only appear in the obsession with western dress, but also in the use of English and integrating it with Arabic in their speech. This led to the formation of a new information system that affects the socio-cultural structures of the societies, carrying many social and cultural crises, especially in societies that import culture without possessing ability to produce or confront, and thus its cultural specificity is in danger of being obliterated and disappeared. According to Crystal "once a world language is in place, other languages will simply die away." (2003:15). Language "blooms through utilization and contact or it loses its weight through marginalization or lack of usage" (Benkharafa, 2013, 205) 
The language of the nation that does not produce science weakens. Language is stronger when it becomes the language of science and the language of knowledge, which qualifies it not to dissolve in another language, and losing its identity. The Arabic language suffers from the danger of melting in English because of the phenomenon of fascination of the west. Westernization is a case of association, admiration and imitation for the western culture, and applying western values and lifestyles, so that the individual, the group or the society that has that attitude becomes strange in its tendency, emotions, habits lifestyles, general taste and attitudes towards life. This is reflected in the form of some language practices, represented by what is called 'linguistic finery' or 'altabaruj $\bar{a} l u \bar{g} a w i$, like finery in appearance and clothing, and the following are some examples:

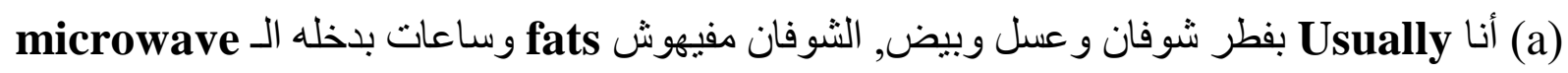
فيه option. تاني؛ ممكن تستعملي فاكهة مجففة.

I usually دائها have oat, honey and eggs for breakfast, oat is fat دهون free. Sometimes I put it in microwave الميكرويف. Using dried fruit is another option اختبار.

$$
\begin{aligned}
& \text { spotlight من كتر ماانتي حاسة إن إنتي تحتي (b) } \\
& \text { You feel restless قلق دائرة الضوء } \\
& \text { عشان تكوني elegant لازم وشك ييقى كده. (c) } \\
& \text { To be elegant أنيقة your face should be like this }
\end{aligned}
$$

\subsubsection{English and association with certain domain}

English is a colorful and rich-vocabulary language. One of the main reasons for the frequent use of English words is the "lack of meaning" or the word or so-called "lexical gap" or "lexical hole". According to Trask, the term refers to "the absence of a hypothetical word which would seem to fit naturally into the pattern exhibited by existing words" $(1993,157)$. Scientific advance has created many medical, technical and scientific terms that have spread among people. Al-Khatib and Sabbah (2008) state that English terms for science and technology or academic issues are used because the person does not know the equivalent terms in Arabic or finds it easier to use the English terms than to think of their Arabic counterparts (p. 56). This could be noticed in the following examples 


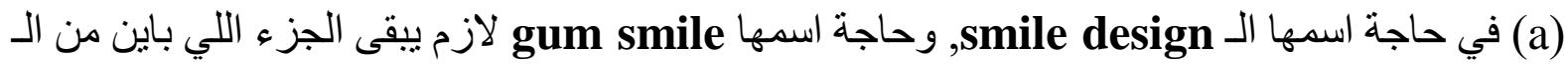

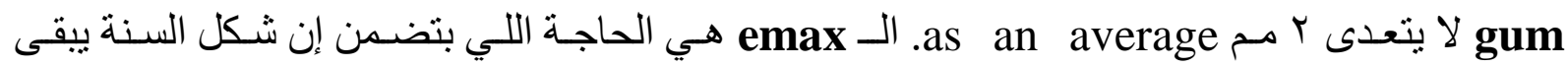
. السنان دي معمولة natural

We شكل الابتسامةand gum smile ابتسامة لثوية. Gum-appearing part should be have smiledesign guarantees the teeth natural look. Those teeth 2millimetre as an average. Emax smile-designed/ايماكسare

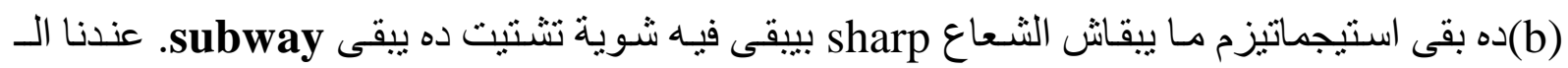
contra vision

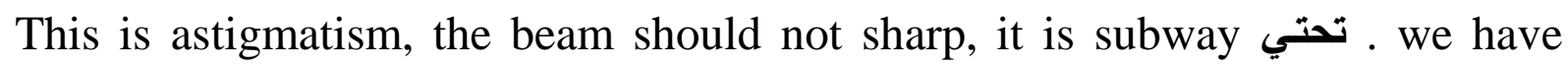
femto lasik تصحيح النظر باستخدام الفيمتو, new process for lasik and curing retinal damage.

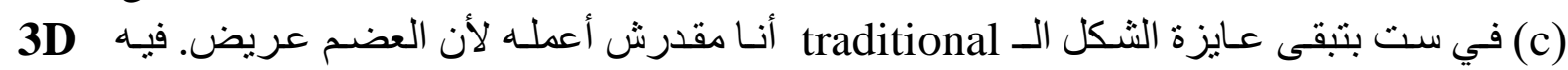
application

Sometimes a woman wants the traditional الثكل التقليدي shape and I cannot make it because the bones are wide. We have 3D application تطبيق ثُلاثي الأبعاد before and after the operation.

إحنا محتاجين abdomen لل دull sculpture (d) We have to make abdomen full sculpture نحت كامل لمنطقة البطن دئنة problem but weak muscles problem.

$$
\text { Marriage consultant الـ (e) }
$$

We do not have marriage consultant دوج استثاري زوناك دواج our country, it is abroad.

It has been noticed that guests use English words that have equivalents in Arabic. But sometimes using English could be attributed to the absence of lexicalization of some terms or concepts in Arabic such as 'microwave', 'smile design' , 'gum smile', 'emax' , 'astigmatism', 'femto lasik'...etc. Myers-Scotton (1993b) states that people may switch languages because "their facility in the 'unmarked code' fails them" (476), but it is not so often.

\subsubsection{Social linguistic prestige associated with English}

English is a prestigious language because it is associated with power and wealth (Crystal, 2003). In the English-speaking world, the linguistic behavior of people is greatly affected with English which enjoys high prestige and has an elevated position in Arab communities. It has been noticed that using English gives prestige, modernity and a pinch of professionalism to the speaker. According to Al-Issa and Dahan (2011), people "feel the need to master English 
because they view it as the language of knowledge in addition to the prestige it brings the user" (p. 17). Myers-Scotton (2001) states that any given code choice can be explained according to the speaker's motivations. According to the Markedness Model, speakers deliberately choose to use a marked code to change their relative position or status, or, in other words, to negotiate a new rights and obligations set. Speakers intentionally use English to be more appreciated. This could be illustrated in the following examples:

Ups and downs العلاقة بتكون ماثشية كويس, بس مفيش مانع من فتر ات الـ (a)

Even if the relation is good, there are ups and downs تقلبات

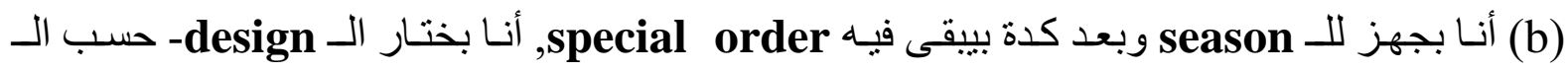

it depends on the materials -بس أسمكن أعمل Special order I am preparing for the season طوسم, we have special order طلبات خاصنة I choose the design التصميمaccording to the dress الفستان. I can make special order but it depends on the material ده بيتمد علي خام القماش

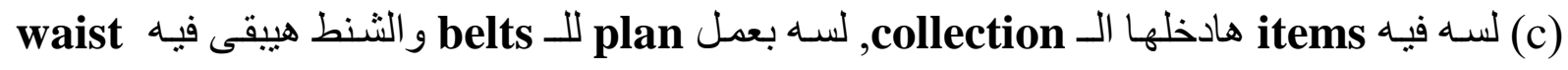
.bags

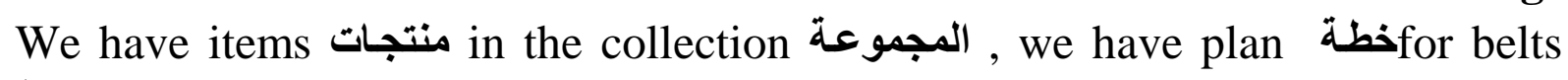

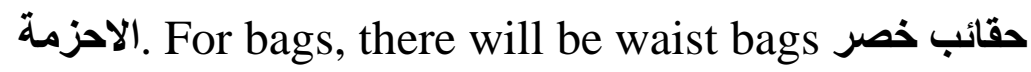

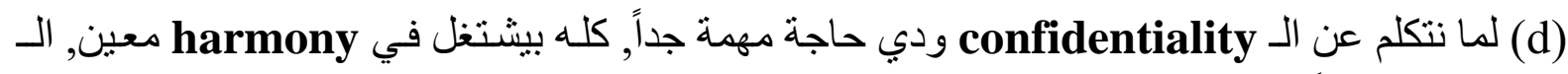

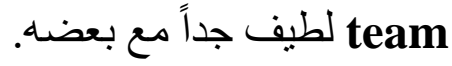

الفريق is really an important thing. The team السرية 1 are working in special Confidentiality harmony ألفة . They are nice to each other

إن experience أنا بحس من اعتي إن الر اجل عشان هو الـ upper hand في كل حاجة بيحس إن الفلوس بتعمل قوة للست.

According to my experience الخبرة, I see that man is the upper hand اليد العليا in the relation he sees that money can make woman more powerful.

decision maker الأب موجود بس أنـا (f)

I am a decision-maker صانع قرار more than the father misconception (g)

There is a misconception مفهوم خاطئconcerning scholarships

In the examples mentioned above, English is associated with modernity (Alfarhan, 2016) as the speakers use of English could be replaced by Arabic. It is reasonable that speakers are aware of the preferred language for the speech. They are rational actors whose behavior is purposeful. They optimize the 
rewards to have the best outcome (Myers-Sotton 2002). In the examples mentioned above, English is used for showing off. This Finding is in agreement with Ali (1999).

\subsubsection{Nativization of English words into Arabic}

Arabic morphological adaptation of the English words has been noticed in the following examples

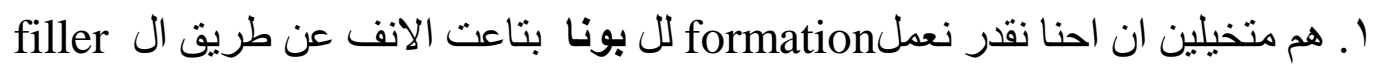

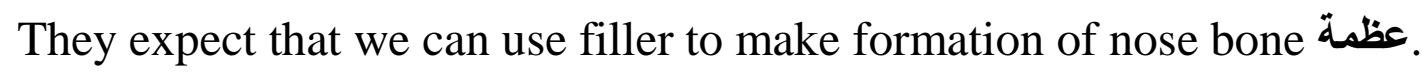

$$
\text { r. لما بتكلم معاك بتعرف علي اتيتودك. }
$$

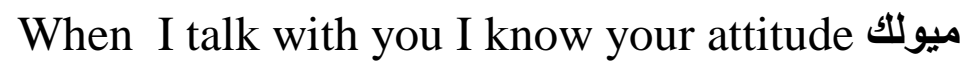

$$
\text { r. برج التور من أذكى الأبر اج, الثغل عنده رقم واحد لما بيتلخبط في الثغل ده بيأثر على موده }
$$

taurus is one of the smartest signs. He loves work to the extent that it may affect مزاجه his mood

$$
\text { ع. ر اجل برج السرطان ميقدش يعيش من غير ست لأن هي اللي بتهندله حياته. }
$$

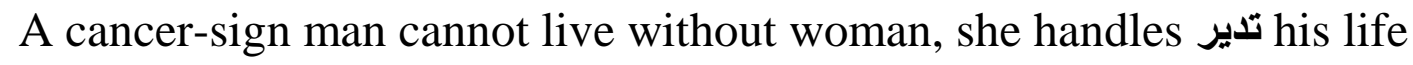
0. كده ممكن أحط مكسر ات مش متحمصة اللي هي ال raw بس في تريكاية ال peanut butter ودي

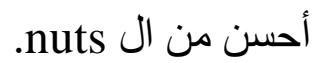

I can put raw nuts, but there is a trick حيلة peanut butter is better than nuts ז- في الحالة دي العيان لازم يتفنتل.

In this case, the patient should be ventilated بؤكسج العمله:

$$
\text { V- V لازم نتأكد ان المريض اتكنشس بعد العطلية. }
$$

We should make sure that the patient is conscious عاد للوعي بعis after surgery

$$
\text { Aـ الثيف بيمرين اللحمة ويفرزنها عشان تبقي جاهزة. }
$$

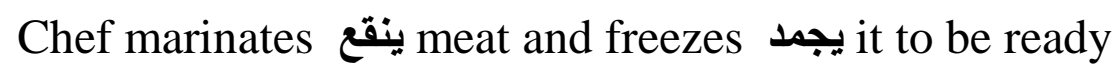

From the examples mentioned above, it has been noticed that English words are adapted morphologically in the Arabic language. This has been shown in the suffix '-a' attached to the word 'bone' in first example to be pronounced 'bona' بونا. The possessive clitic pronoun '-k' is added as a suffix to the English noun 'attitude' to be 'attitudak' أتيديودك (your attitude), and the possessive masculine pronoun is attached to the noun 'mood' to be 'mooduh' موده(his mood). In the fourth example two Arabic present verb maker 'bit-' and third person singular masculine pronoun are attached to the English verb 'handle' to be 'bithandiluh' تريكايه 'بتهندله by adding Arabic suffix '-aya'. In the sixth example we have the word 'yitvantil' يتنتئit(to ventilate), the prefix 'yit' is attached to the verb 'ventilate' with a gemination of the ' $n$ ' sound. In the seventh example we have the adjective Journal of Scientific Research in Arts 
'conscious' and the Arabic suffix '?it' to be ' 'itkanŠas' اتكنشس which means (to be conscious). In the eighth example, the use of the verb 'marinate' is transformed to 'biymarryin' بيمرين which means (to marinate), The Arabic present verb maker 'biy' is attached to the verb, the ' $r$ ' sound is geminated and ' $t$ ' sound is lost. The same thing is in the other verb 'yifarrzenha' (to freeze). The Arabic present verb maker 'yi-' and the object third person masculine pronoun 'ha' are attached to the English verb 'freeze'. A lot of other verbs are used by the Egyptian people like 'yirafriš ' (to refresh), 'yisaryiš ' (to search), 'yi makkap' (to make up), 'yifayyayal' (to file), 'yiŠayyar' (to share), 'yiŠayyik' (to check)...etc. Speakers follow the well-formedness of the constraints of the ML (the language that provides the morphosyntactic frame) which is Arabic.

\subsubsection{Structural patterns of English in Arabic}

Matrix Language Frame (MLF) model is proposed by Myers-Scotton (1993b, 2002) to investigate the social motivations and the linguistic patterns of code switching. Myers-Scotton's notion is related to intrasentential and intersentential code switching to examine the matrix language (ML) and Embedded Language (EL) in sentence structure. ML language plays the dominant role in code switching while EL plays lesser role. In the present study, Arabic language is the ML and English is the EL. Intrasentential switches occur when there is a switch in languages within a single sentence While intersentential CS deals with CS across sentences (Myers-Scotton 1993b).

The corpus of this study conforms to Myers-Scotton MLF model as Arabic provides the most morphemes (ML) and it determines the grammatical frame whereas the EL (English) is embedded or inserted. The analysis of the data has shown that English used in the talk shows includes three structural levels: single word level (nouns, verbs, adjectives, and adverbs), phrase level and sentence level. This could be illustrated in the following:

\subsubsection{Single word Level}

\section{a. Nouns}

( الوزير دلوقتي بقى بيركز على الـ System بتاع التعليم عن طريق الـ activities.

Now in the education system, the minister focuses on activities

$$
\text { calories كليلة جداً. }
$$

This amount of milk has low calories.

$$
\text { (relationship مع دايماً بييقى فيه الـ client بتاعي. }
$$


I always have a relationship with my clients

$$
\text { ( ) فيه حذ بييقى عايز quote معين. }
$$

Sometimes a special quote is requested.

$$
\text { (0) النهاردة حصل استحو اذ على ثروة capital وده بيغير الـ market }
$$

Today capital dominates and this changes market cash.

\section{b. Verbs}

$$
\text { (1) فيه ناس بطبيعتها مش بت share أو مش بتقول اللي عندها. }
$$

Some people do not share or express their feelings

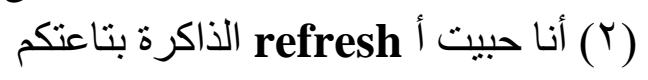

I just wanted to refresh your memory

$$
\text { measures عشان ت make sure أن إن كل حاجة آهنة. }
$$

You are taking measures to make sure that everything is safe.

$$
\text { ( ) الجير ده عمال بي expand على حساب العضم اللي حو الين السنة. }
$$

Calcus expands and affects the bones around the tooth

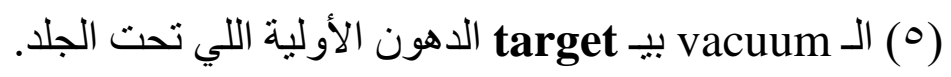

Vaccum targets the primary fats under the skin.

$$
\text { (7) إحنا هن focus على الموضوع. }
$$

We will focus on the topic

\section{c. Adjectives}

$$
\text { (1 ) عشان تكوني elegant لازم وشك ييقى كده. }
$$

to be elegant, your face should be like this

$$
\text { (r) ده بقى استيجماتيزم مييقاش الثعاع Sharp. }
$$

This is astigmatism, the beam should not sharp

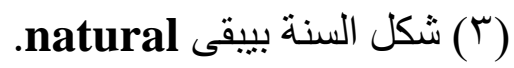

tooth has a natural shape

$$
\text { (§) إلبسي بنطلون بس مش classy. }
$$

Do not wear classy pants

$$
\text { (0) اللي عايز يعمل حاجة غلط irrespective هيعملها. }
$$

If anyone wants to do any irrespective behaviour, he will.

\section{d. Adverbs}

Shares of around $50 \%$

$$
\text { (1) الأسهم اللي بتحتل around خمسين في المية بتحقق مكاسب عالية. }
$$

$$
\text { (r) نتقابل برة عشان ميحصلش إحر اج usually ده اللي بيحصل. }
$$

Let's meet outside to avoid embarrassment which usually happens.

$$
\text { (r) أقل من النص يعني almost أربعة كيلو. }
$$

Less than half almost four kilos 
( ) د ده مكان فيه استثمار و definitely

This place an investment place and definitely has a lot of work

\subsubsection{Phrase Level}

( ) ( ) إنتي بتعطلي حاجات للرجالة و لا for women بس.

Are you designing for men or only for women?

for everybody (Y) هي سهلة في اللبس

It is easy to wear for everybody.

on the spot لازم تنتف.

There are things that are on the spot, should be done.

\subsubsection{Clause Level}

(1) ساعات بيقى it is sentimental أكتر, بيعكس شخصينك وروحك.

Sometimes it is sentimental, it reflects your character and spirit

(r) خالد ما طلعش الست غلطانة في البرنامج thank you Khaled, you are a gentleman. Khaled said in the program that the woman wasn't wrong, thank you Khaled, you are a gentleman

(T) أوقات بيقى it is not the face يقى إزاي الست بتعرف تلبس.

Sometimes it is not the face it is what woman chooses to wear

He feels that it is taken for granted

(๕) هو كدة بيحس خلاص إن it is taken for granted

(0) اتأنى في الاختيار و أحسن الاختيار to be true to be good وخلاص.

Be wise and right in my choice to be true to be good

In the Arabic corpus, the largest category of English words are of single nouns. The inserted English elements in the Arabic speech have exhibited different structural patterns. intrasentential code switching is mostly used. Egyptian people tend to add Arabic prefixes to English verbs such as 'yi' such as 'yimention' , 'yi-subscribe' or 'a' such as 'a-google' (to google), 'a-manage' (to manage), 'a-handle (to handle) They also indicate that English is dominant in the speech of the speakers with different frequency occurrence of each category. 


\section{Findings \& Discussion:}

The data have revealed that using English in talk shows is a conversational process governed by some sociolinguistic factors and grammatical constraints. Code switching behavior depends on the speaker's preference which constitutes one variable. The other variable is the topic. Regarding the distribution of English in some selected Egyptian talk shows, the results have shown the high occurrence of single-word level $(76 \%)$ as nouns constitute $(61.8 \%)$, then adjectives $(6.8 \%)$ followed by verbs $(4.9 \%)$ and rare occurrence of adverbs (2.5\%).

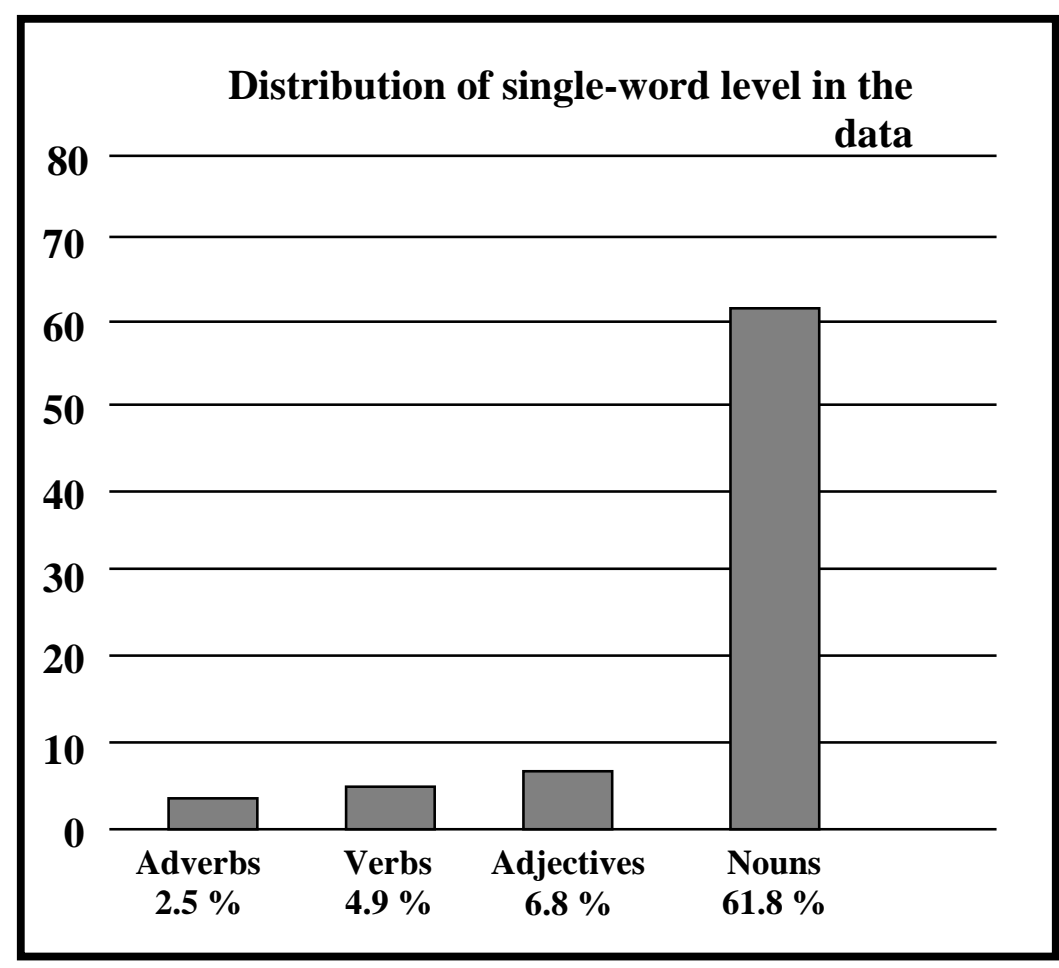

Figure 1 shows the distribution of single-word level in the data

Phrase-level constitutes (17.5\%), clause-level occurrence is few as it represents (6.5\%).This may be due to the fact that the use of English single words doesn't require mastery of the English language as phrases and clauses. 


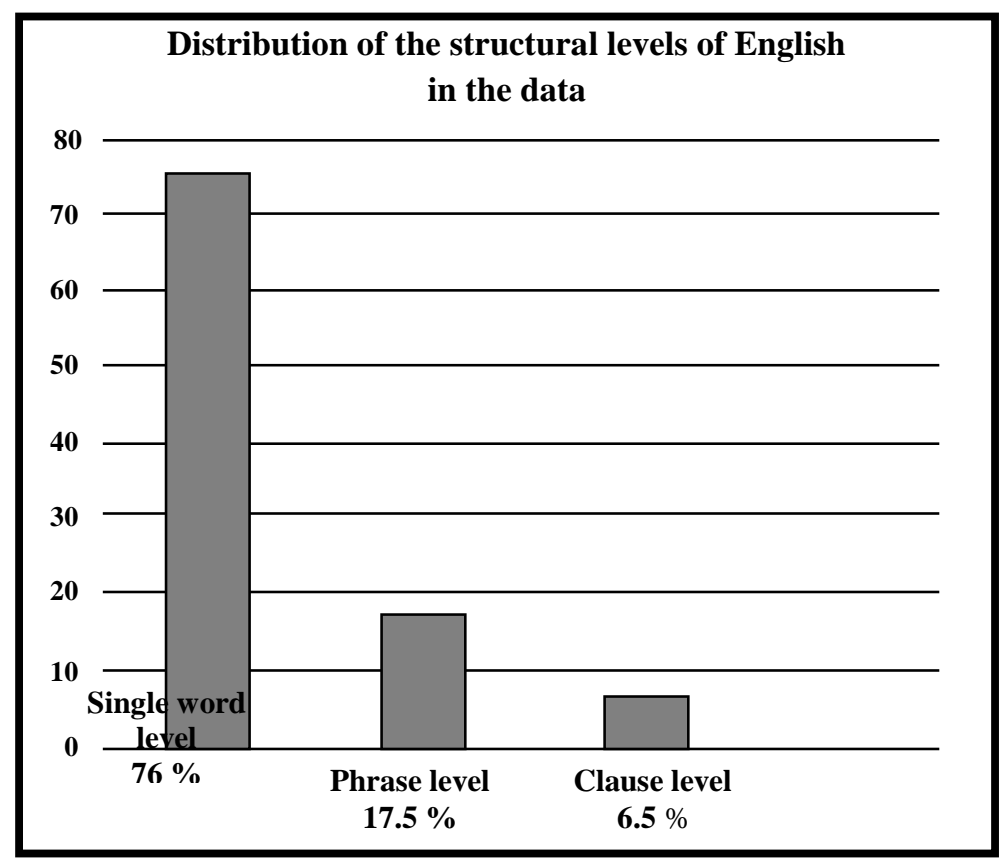

\section{Figure 2 Distribution of the structural levels of English in the data}

The data have also shown that the rate of using English in Arabic speech varies due to the nature of the topic. English plays the role of the dominant language in social issues (33.6\%), fashion and beauty (19.6\%), food (17.5\%), medicine (16.9\%), economy (12.8\%). a finding that is in line with those of Ali (1999) and El-Samaty (2002).

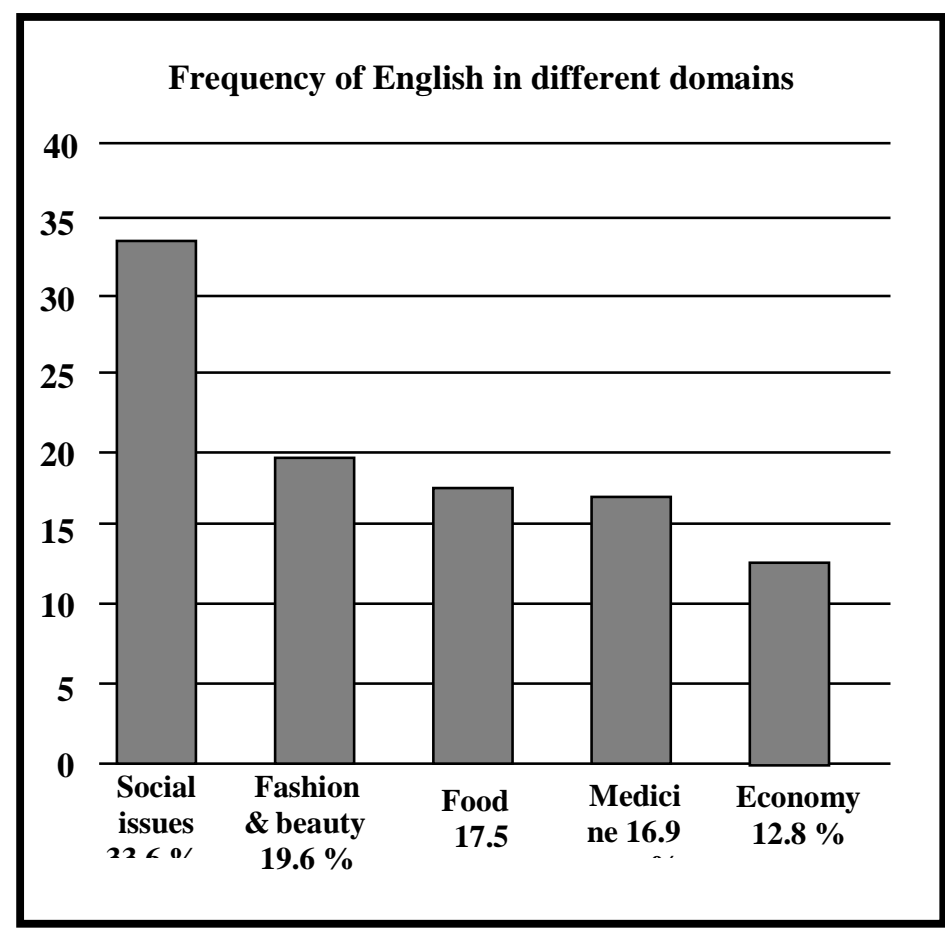

Figure 3 Frequency of English in different domains 


\section{Conclusion \& future recommendation}

The study is aimed at examining the reciprocal impact between Arabic and English. It investigates the phenomenon of English dominance on the colloquial Arabic in the Egyptian society. It seeks to find out the causes and factors of people's tendency to favor English in their speech. It has been noticed that the continuous injection of English words into the Egyptian spoken language affects the Arabic language and people's cultural identity. Arabic has become a means of daily routine interaction among society members, and English has become a means of cultural communication. Some programs on T.V. and Youtube have been selected to examine this linguistic phenomenon. Using Myers-Scotton Markedness Model (1993a, 1993b), it has been found that guests, callers and presenters use English in their speech purposefully for showing off, clarity, easiness of English words and lexical gap. Myers-Scotton (2000) sees that competent speakers know which code is appropriate for which occasion. speakers are aware of the preferred language for the speech. They are rational actors whose behavior is purposeful. They optimize the rewards to have the best outcomes. It has been found that speakers on those programs use intrasentential code switching more than intersentential code switching for easiness. They follow the well-formedness of the constraint of the ML (the language that provides the morphosyntactic frame). The spread of this phenomenon is due to Egyptians' fascination of the west and modernity. The conflict between cultural identity preservation and the global communication could be resolved if individuals recognize that speaking English is not a statusmarker. It is suggested that more research should be conducted in different settings to support or refute the findings or the results of this study. 


\section{References}

Akeel, E. (2016). Investigating Code Switching between Arabic/English Bilingual Speakers. English Linguistics Research Vol. 5, No. 2, pp 57-64.

Al Allaq, W. (2014). Arabic Language in a Globalized World: Observations from the United Arab Emirates. Arab World English Journal, AWEJ, 5 (3)

Alfarhan, I. (2016). English as a Global Language and Its Effect on Culture and Identity. American Research Journal of English and Literature, 2, pp1-6

Ali, D. 1999. Code-switching among Egyptian university learners of English. M.A. thesis, Faculty of Arts, Cairo University.

Al-Issa, A., \& Dahan. L. (2011). Global English and endangered Arabic in the United Arab Emirates.

Al-Khatib, M., \&Sabbah, E. (2008). Language Choice in Mobile Text Messages among Jordanian University Students. SKY Journal of Linguistics, 21, 37-65.

Aziz, Y. (1967). The influence of English Grammar, Syntax, Idiom and Style upon Contemporary Literary Arabic. PhD. thesis, St. Andrews University.

Benkharafa , M. (2013). The Present Situation of the Arabic Language and the Arab World Commitment to Arabization. Theory and Practice in Language Studies, 3 (2), pp. 201-208.

Ben Nafa, H. (2013). Code-switching among Arabic - English Adult Bilinguals in the UK: Syntactic Structures and Pragmatic Functions. M.A thesis, university of Manchester, the Faculty of Humanities.

Crystal, D. (2003). English as a Global Language. Cambridge University Press, second edition

Dahan, L. (2015). Critical Examination of the Significance of Arabic in Realizing an Arab Identity: the Perspectives of Arab Youth at an English 
Medium University in the United Arab Emirates. Ph.D. dissertation, University of Exeter

Darwish , H. (2015). Arabic Loan Words in English Language. Journal of Humanities and Social Studies. 20 (7).

El-Samaty, M. 2002. A study of code-switching among educated Lebanese as reflected in television talk shows. Cairo, American University: M.A. thesis.

Fathia Hanani. (2009). Impact of English on young Arabs' use of Arabic UAE. MA thesis, Sharjah.

Hamouda , A. (2015). Arabic - English Code switching in the Egyptian Talk Show "shabab beek". MA thesis, Arizona state university.

Hassan, B. (2012). Language and Identity: Impact of Globalization on Arabic. Annuals of the Faculty of Arts, Ain Shams University, 40.

Hassan, B., \& Al- hussien, A. (2016). Instruction through the English Medium and its Impact on Arab Identity. Arab World English Journal,7 (2),pp 342-357. Hopkyns, S. (2017). A Conflict of Desires: Global English and Its Effect on Cultural Identity in the United Arab Emitaes. PhD dissertation. University of Leicester.

Kachru, B. (1994). Englishization and Contact Linguistics. World Englishes,13(2), pp135-154.

Myers-Scotton, C 1993a. Social motivations for code-switching: Evidence from Africa. Oxford: Oxford University Press.

----. 1993b. Common and uncommon ground: Social and structural factors in code-switching. Language in Society 22. 475-503.

----. 2002. Frequency and intentionality in (un)marked choices in codeswitching: "This is a 24-hour country". The International Journal of Bilingualism 6 (2). 205-219.

Trask, R.(1993). A Dictionary of Grammatical Terms in Linguistics. London: Routledge. 


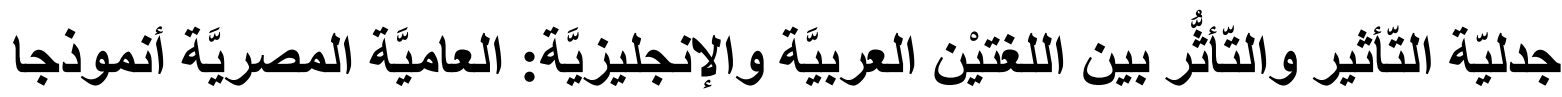 د. أماني حامد$$
\text { كلية الآداب قسم اللغة الإنجليزية الو ادي الجديد }
$$

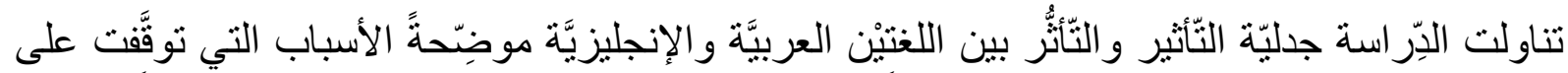

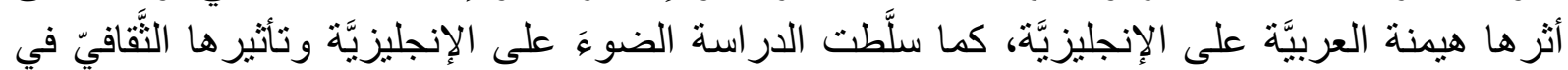

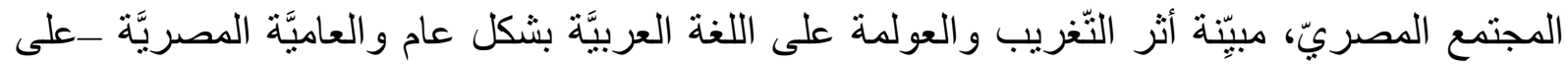

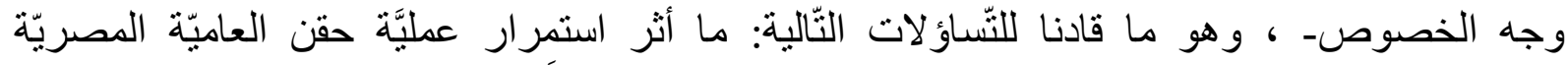

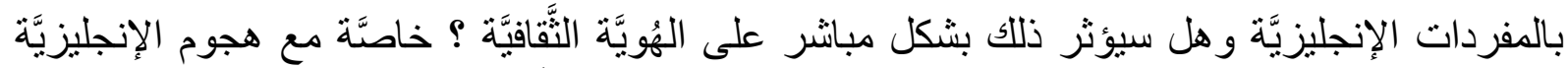

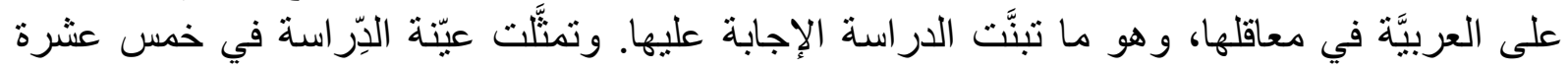

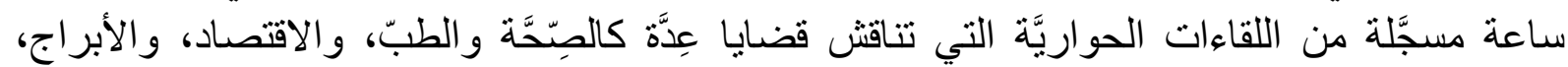

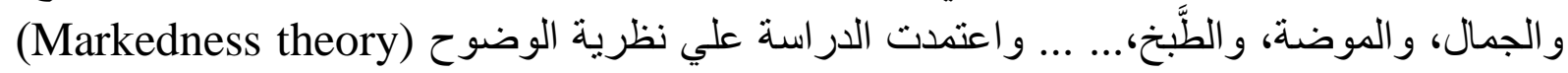

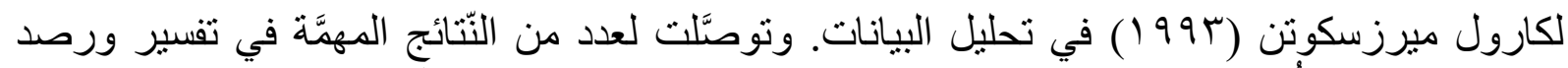

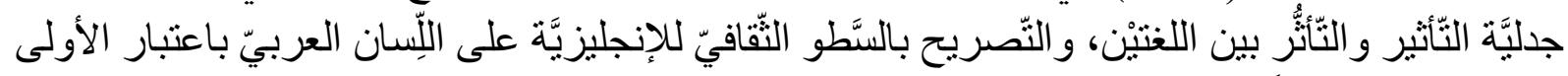

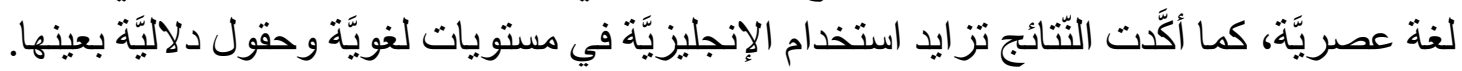

الكلمات المفتاحية: جدليّة التَّأثير ، العاميَّة المصريَّة، نظرية الوضوح ، الهُويَّة الثَّقافيَّة 